\title{
Who Remembers those "Undocumented Minors"? Locating the Genealogy of the Oppressed in Valeria Luiselli's Tell Me How It Ends
}

\author{
Indrajit Mukherjee \\ Assistant Professor, Dept. of English, Nistarini Women's College, Research Scholar, Vidyasagar \\ University. Email ID: perfectindrajit.mukherjee@gmail.com
}

\begin{abstract}
We can always look upon the intersection of history and events as an exciting façade, full of deceptions, half-baked truths, and awkward reconciliations in the framework of cultural studies. The Mexican author Valeria Luiselli's Tell Me How It Ends (2017) attempts to trace the evolution of a set of social, political, and cultural circumstances that are pregnant with significance in the traumatic past of millions of Latin-American children refugees in the United States. First, the article will unpack how Luiselli's impalpable domain tries to connect the unresolved experiences of the violent wounds of those children's deportation and dislocation from Guatemala, Honduras, and Mexico with their unfortunate encounters in the foreign land. Second, it will attempt to dismantle, disrupt, and deconstruct the construction of America as a heteroglossic space around the challenges of those displaced children by displaying some questions addressed to them at the immigrant court. Finally, the proposed paper will critically scrutinise how this non-fictional work follows the creeping imperialist approaches of the United States through the hazes of childhood recollections, making a heartfelt appeal to everyone to halt discrimination, racial hatred, and poisonous ignorance. Applying Agamben's idea of the homo sacer, such a study will bring to the fore the dialectics of postcoloniality in the United States, where undocumented children's claims to identity formation and self-determination processes would be at odds with the more comprehensive national identity in contemporary times.
\end{abstract}

Keywords: History, Refugees, Heteroglossic, Imperialist, Homo Sacer, Identity.

Tell Me How It Ends (2017) talks about the writer's experiences as an interpreter for Central American child refugees, exploring one of the most complex and unequal cross-border relations in light of the rise of Donald Trump to the throne of power in 2016 (Raul Hinojosa-Ojeda and Edward Telles, 2021, p. 21). The genesis of the book traces back to the writer's problems as a Mexican lady in the United States, illustrating that the problematics of citizenship right in America is based "on the notion of being a serving citizen, rather than one who deserves rights" (Rudrappa, 2008, p. 308). The narrative demonstrates the politics of "the still ongoing refugee and migration crisis" (Nedoh, 2017, p. 1) through the microcosmic presentation of one of contemporary 
America's lost and forgotten figures. Those undocumented children in America are among the most disadvantaged individuals of Latin American countries such as El Salvador, Guatemala, and Honduras, "the tropic zone uneasily bordering the U.S. south" (Franco, 2002, p. 108). They flee terrible poverty and horrific experience in their devastating native place, prompting us to consider the seemingly benign crime of being born at a specific moment and location continuum. Their struggle raises several questions in our critical faculty: What motivates these youngsters to escape their homeland? Why do they choose the United States as their final destination? How do they take to get into the United States? What is their identification status in this alien space? What does this foreign land stand for them? Furthermore, last but not least, how does it all come to an end?

First, we must consider how Latin America's tragic past leads to tremendous poverty, political genocide, oppressive government, corrupted politicians, environmental plunder, and health risks. Luis Leal (1989) demonstrates how their past gets littered with Obregons, Carranza, Diazzes, broken promises, and revolutionaries who try to save the continent from the brink of impending disaster (pp. 1215-27). There have been several insurgencies on this continent since 1821, illustrating that things have changed, governments have fallen apart, revolutions have become institutionalised, but tyranny has remained in place. A recurring pattern of their imprisoned past preceding each insurgency was a passionate explosion of dreams and aspirations, ideas and sentiments, followed by a shattering blow to those objectives. The bloody Mexican Revolution of 1910, in which intellectuals and liberals started to oppose El Porfirio's thirty-four years-long autocratic regime, was one of the most phantasmagoric experiences in the country's postcolonial history. It aimed to abolish feudalism, metamorphose the economy via rapid industrial and technological advancements, terminate the nation's economic and political dependency and set up a genuinely democratic society. However, even after eight years of this revolution, thousands of rural citizens from that space lived in utter misery and disillusionment due to the emergence of the totalitarian regime as "a swelling and life-giving tide" (Folena, 1989, p. 235), leading people to remain docile and passive and isolate themselves from that space and immigrate to the United States for a better livelihood in the face of persecution. For example, Garcia Marquez's narrative (1967) shows how the North American Banana Company, alias the United Fruit Company, metamorphosed this region into a hotbed of modern economic colonialism, murdering a considerable number of workers during a strike in Magdalena in 1928. Jose Marti (1963), the outstanding political thinker of Latin America, explains how the continent's challenge has been twofold: gaining independence from Spanish invaders and preventing a new imperialist dominance by growing imperialists such as the United States. The present text (2017) becomes a stinging indictment of the hegemonic narrative of the barbarians with their "chaos, their disease, their filth, their brownness" (p. 15) in the construction of the neocolonial civilisation in Latin American countries.

Rosario Castellanos (1988) shows how in Mexico, "the daily social behaviors of beings, so dissimilar, produces phenomena and situations that began by interesting the anthropologists, and have never stopped appealing to writers who struggle to get to the very roots of those extreme of human misery" (p. 33). The return of the violent military dictatorship, which in most parts of Latin America's politically independent countries imposed by incorporating its totalitarian regime's unidimensionality, coincided with the arrival of accelerated modernisation on the socio- 
political site in the latter half of the 1970s. For example, the Salvadoran Civil War in 1979-1992 led to intense violence, gang rape and coercion, physical and psychological torture, forced labour and death threats, ignorance, and abandonment (Luiselli, 2017, p. 62) under the reign of President Enrique Peña Nieto. Prof. Indrani Mukerjee remarks:

"Citizens have nothing to look up to as an ideology, whether social or religious or political, as everything fails them. [...] At present, it shows only violence, hopelessness and a prosaic world of drugs, AIDS, ecological disaster, displacement and distress." (Mukherjee, 2011, p. 386)

The continent cannot produce even the bare minimum of industrial, governmental, and agricultural job opportunities to meet the demands of the overabundance of its inhabitants in this pitiful scenario. Currently, the continent's economy is nearly wholly reliant on the US, and the continent is merely a nominal single-party democracy, with the President yielding ultimate authority. Their long history of failure and betrayals has conditioned the native people to anticipate and accept the worst, a situation that the country's early revolutionary administrations overlooked (Mukherjee, 1998, p. 35-36). Luiselli (2017) brings to the fore the dismal socioeconomic condition of the continent through an interview with an undocumented teenage girl when she vividly describes how a group of thugs kidnapped her buddy and pursued her home on motorcycles in their homeland every day (p. 88). The continent's drug gangs, such as MS- 13 and the Calle 18, have developed into a kind of worldwide army, with over 70,000 members whose brutality surpasses that of military violence at the border, illustrating "a form of macabre theatre addressed not only to rivals but also to the public" (Franco, 2013, p. 15). That is why Agamben (2000) states, "From the beginning, many refugees, who were not technically stateless, preferred to become such rather than return to their country" (p. 16).

To address the second question, we must look upon the construction of the United States as part of the imagined geography under foreign eyes. From time immemorial, people consider the land of America not as a geopolitical space but as a concept in which "saint, savage, sage/ Fuse their creeds in one" (Browning, 1864, p. 366). It encourages the seemingly imperceptible but everlasting love flow that delights in conjuring hearts rather than lands, therefore saving everyone from the primrose path of dalliance and ultimate ruin. The romantic notion is that the history of the United States gets torn by a fight between the constructive spirit of the machine, which seeks rhythm, order, and uniformity in social structure, and the creative spirit of man, which wants freedom and love for self-expression. In accommodating a diverse population throughout the universe, it has significantly suffered while rejecting none, dissolving all differences of rank and race to bring everyone under the umbrella of one universal religion. The United States has bound sundry on the principle of universal brotherhood "to realizing the infinite in the finite world, and attainment of the unity of all beings" (Alam, 2020, p. 169). Despite geographical isolation or governmental suzerainty, it has a profound underlying unity beyond numerous differences in blood, colour, language, gender, and manner, leading to juxtaposing people from multiple backgrounds. However, Ali Behdad (2005) shows how such representation of the US has become a myth or a "forgetful nation" (p. 1) because the continent "produces a pseudo-historical consciousness of the present" (p. 4). The experiences of those undocumented minors in this space tell a different story altogether, demonstrating how precarity becomes a generalised "form of 
regulation that distinguishes this historical time" (Butler, 2015, p. vii).

The journey of undocumented minors from their home country to witness "the other side of horror" (Luiselli, 2017, p. 20) in the United States is extremely difficult, with numerous children have breathed their last or poorly wounded in La Bestia, either as a consequence of derailments or due to falling off the running train's roof at night. Even the tiniest blunder on their journey through Tapachula, Chiapas, Tenosique, and Tabasco might be catastrophic, evoking analogies to La Bestia or a vacuum that sucks inattentive passengers into its metal bowels. When they arrive at the US-Mexico border, the Immigration and Customs Enforcement treats them using a massive human refrigerator that is constantly blasted with cold air to keep these "illegal aliens" (ibid, p. 87) from rotting and harbouring all kinds of horrible illnesses. The author provides a case study again: the AILA endorsed a complaint filing in July 2015 after discovering that a detention centre's authority administered two-fifty children adult-strength hepatitis A vaccines in Dilley, Texas (ibid, p. 22). They had kept more than one lakh and two thousand unaccompanied kids at the borders between April 2014 and August 2015, according to a newspaper report published in the summer of 2015 (Luiselli, 2017, p. 38). These incidents illustrate how tension arises in "the borderland like a virus" (Anzaldua, 1987, p. 4), particularly how border security force as the American conceptmetaphor creates the "geographical and political space as lines on a map simultaneously inscribe the body's topography" (Donnan and Wilson, 1999, p. 129). Undocumented girls are also subjected to physical abuse and rape in this space, demonstrating how militarisation at the border marginalises women, particularly those from minority communities (Banerjee, 2010, p. 115). Anustup Basu (2020) shows how in India, "the specter of the concentration camp [...] haunts Trump's detention centers for Latino immigrants at the United States-Mexico border" (p. 19), illustrating how the detention camp nowadays becomes "a space of exception [...] in which not only the law is completely suspended but fact and law are completely confused" (Agamben, 1998, p. 170).

After landing in the United States, it has become a modus operandion their part to appear in an immigration court, which, like a refugee camp, provides a metaphor for how sovereign power seems to be (Agamben, 1998, p. 132) and makes them "appear virtually as homines sacrl" (ibid, p. 111). Agamben shows how in that space, "the possibility of differentiating [...] between what is incommunicable and mute and what is communicable and sayable was taken from us forever" (ibid, p. 188). Here, the writer's task is to assist those immigrant children in the long mahogany table by asking forty questions in Spanish and interpreting their responses into English for the sake of justice, illustrating that the action of "surviving takes place in language" (Butler, 1997, p. 4). For example, the questions may be "How did you travel here?" (Luiselli, 2017, p. 18), "Do you travel to Muslim- majority countries?" (ibid, p. 31), or "Where did you cross the border?" (ibid, p. 56). She is part of the US Citizenship and Immigration Services' official interview aka "screening" (ibid, p. 11) papers for ten thousand Latin American youngsters trafficked across the U.S.-Mexican border each year. Each youngster comes from a different area, has a different life, and has had a diverse collection of traumatic experiences, yet their narratives all have the same messed-up endings. These unaccompanied youngsters may have no idea where their parents are, or they may have a parent or relative already in the US who has paid for them and accompanied them lawfully. Valeria Luiselli (2017) describes their trials and tribulations thus: 
"They don't have to be given temporary shelter, are not allowed to attempt contact with parents or relatives in the U.S., and are certainly not granted a right to a formal hearing in court where they could defend themselves, legally, against a deportation order." (ibid, p. 52)

She hears about "the stories of deepest horror" (ibid, p. 30) of those Latin-American children and how they received them from their native land, comparing their experiences in Tegucigalpa with those of Hempstead, New York. Nevertheless, unfortunately, the authoritarian regime deports most of these children to their homeland without legal counsel, and "the uncanny image of the children holding those balloons" (ibid, p. 16) haunts the writer all too often in her pensive mood.

Agamben (1999) says that nowadays, the function of law is for judgment only, illustrating that justice becomes a heavenly idea that legal systems attempt to strive to but never ultimately achieve (p. 18). He (1995) shows how the autocracy has made refugee "a temporary condition that should lead either to naturalization or to repatriation" (p. 116) in this era of transnationalism because refugees "represent the breaking point between birth and nationality [...] and they therefore cause a crisis in the dominant narrative---- that is, in the state-nation-territory triptych" (Agamben, 2021, p. 65). Depending on their responses and reactions, these Latin-American children may or may not get legal asylum or special immigration juvenile status, hence an opportunity to work in this space and build up their future. According to Agamben's point of view, this legal asylum or special immigration juvenile status (SIJ) in the United States has become "symptomatic of the consolidation of the ancient biopolitical truth of sovereignty" (Philips, 2014, p. 297). If any child qualifies for one of these conditions, they can lawfully live and eventually seek lawful permanent residency and even citizenship to work in their new country for a better livelihood in the upcoming days (Heyman et al., 2018, p. 771).

On the one hand, the immigrant court prevents these children from reuniting with their parents due to domestic violence or other legal grounds, and that the reunion with their native land is not their interest because "home country poses a life-threatening danger" (Luiselli, 2017, p. 69) to their existence. Legal asylum, on the contrary, is provided to those children who are escaping persecution because of their colour, race, religion, political beliefs, or affiliation with a specific community. These queries look upon as springboards for the writer's investigations into the nature of family and childhood of those children, the idea of community, and, most importantly, national identity and belonging. She (2017) notes, "once you're here, you're ready to give everything, [...], to stay and play a part in the great theater of belonging [...] and [...] celebrate the pilgrims who removed the alien Indians" (p. 98-9). Thus, the displaced subject is political in a foreign, defamiliarised environment that is not necessarily his country, resulting in a contradiction between "nativity" and "nationality", according to Agamben (1998, p. 131).

These undocumented minors in contemporary America embody a modern version of Homo Sacer, a marginalised figure in ancient Roman society; the ambivalent metaphor Agamben explores in his seminal work as "an illuminating point of departure" (Tuastad, 2016, p. 3). According to the rigorous interpretation of old Roman law, Homo Sacer was a sort of person who could not be ritually sacrificed but might be killed by anybody, illustrating their precarious life in early Rome. While illustrating "an inner solidarity between democracy and totalitarianism" (Agamben, 1998, p. 10), he cites several historical examples from ancient Rome by comparing 
them with various models from other periods of European imperial history to illustrate the oppressive ideology of the autocratic regime. He explores how the biopolitics of totalitarian regimes produce such lives in State of Exception (2003) and "defies general codification" (Agamben, 1998, p. 9), leading us to look upon the pitiful state of these youngsters at the hands of the white American government. Luiselli (2017) depicts white Americans' attitudes toward them thus:

"Beware the locusts! They will cover the face of the ground so that it cannot be seenthese menacing, coffee-colored boys and girls, with their obsidian hair and slant eyes". ( $p$. 15)

So the precarious life of Homo Sacer, "a disquieting element" (Agamben, 1998, p. 131), becomes a metaphor for the sorrowful lives of these migrant Latin American children that may be taken away without a trial and whose murder at the border does not create any prosecution. As Agamben says, "Bridging to light the difference between birth and nation, the refugee causes the secret presupposition of the political domain--- bare life--- to appear for an instant within that domain" (ibid, p. 131) in the hegemonic "deployments of power" (Agamben, 1998, p. 171).

Agamben (1998) shows how the refugee to the sovereign state becomes "a limit concept", calling "into question the fundamental categories of the nation-state" (p. 134). This narrative shows how America considers these innocent Latin Americans as "bands of organized criminals" (Luiselli, 2017, p. 73) through introducing the priority juvenile docket in the reign of Barack Obama, which is "the government's coldest, cruelest possible answer to the arrival of refugee children" (ibid, p. 41). It illustrates how anti-immigration discourses of oppressive measures against these children have become part and parcel of a more extensive anti-immigration rhetoric becoming normalised in the United States. The twofold exceptions to Homo Sacer's existence, according to Agamben (1998), conform to the structure of the "Sovereign sphere" (p. 55) and that the broken lives of the people in a Sovereign area are always vulnerable to Sovereign power's violence. A sovereign state can legitimately inflict and legitimise atrocity or murder on individuals by stressing the necessity for violence or murder for the sake of "the paradigm of security" (Agamben, 2003, p. 14), as the American government does with these migrant children. Sovereignty decides who lives and who must take extraordinary measures to protect their rights; it is not a crime in the eyes of the law if the sovereign authority takes someone's life out of necessity. Debajoy Chanda (2021) shows how a migrant becomes an image in perpetual motion-one who begins one's trip "into liminality as a citizen with political rights, only to find herself reduced to a statistical category within a statist administration of 'things'" (p. 51).

Agamben (1998) has sought to illustrate how an authoritarian dictatorship's violence and oppression strip people of their human rights and reduce them to a Bare Life (p. 171) alias an "anonymous biological life" (During, 2005, p. 29), challenging the so-called notion that any human life is not just an entity with which one may do whatever one wants. When a person is subject to state-sponsored violent acts, he falls into the category of Bare Life alias "Haplos" (Agamben, 1998, p. 182), in which they have become wild animals with no social, political, and human rights. These illegal children in contemporary times, alias "a biblical plague" (Luiselli, 2017, p. 15), fall under the category of Bare Life because they are victims of Immigration Law's paradigmatic site: the structured processes and procedures used to butcher and smash their existence in the United 
States. According to Agamben (1998), this refugee image exposes the "fiction" of national integrity, as well as all connected political concepts of "people," "public," "citizen," and "human rights" (ibid, p. 131). These children, according to Owens (2009), are the key to a new international politics and paradigm, demonstrating the limitations of any presumed "continuity between 'man' and 'citizen' in the system of nation-states" (p. 578). They make Luiselli identify herself as a companionless stranger among men and sometimes become "ashamed, confused, and sometimes hopeless" (ibid, p. 24), attempting to obtain a green card to live and work as a translator in Trump land.

The complex relationship between Mexico and America became a central theme of Donald Trump's 2016 presidential campaign, with the latter notoriously promoting a border wall between the two countries (Garrett, 2020, p. 1) by expanding "the number of Border Patrol agents, electronic surveillance, unmanned drones" (Klingner, 2018, p. 3). In this psychedelic political climate, where racial notions about identity and belongingness have revived to some extent, his statements garnered a large fan base, allowing him to win the election by a large majority. That is why these undocumented minors "detained by Border Patrol can be deported back immediately" (Luiselli, 2017, p. 52), illustrating the "social tension and potential violence" between these two countries (Fleuriet and Castellano, 2020, p. 1). Moreover, it demonstrates how Trump's and other government officials' public comments dehumanise those children, portraying them as representatives of precarious lives in a distant nation. Precarity, according to Judith Butler and Athena Athanasiou (2013), is the "vulnerability to injury and loss" (p. 20) due to the individual's essential association with the marginalised other. These youngsters create a site for "a more inclusive and egalitarian way of recognizing precariousness" by inviting readers to consider concerns such as their home, food, medical treatment, and legal status in the United States (Butler, 2009, p. 13).

Here, traumatic memories combine with the horrors of the present and foreshadow the future because "the first step was to imprint on the memory a series of loci or places" (Yates, 1984, p. 3). The United States has metamorphosed from a pluralistic space into a "fucked-up place" (Luiselli, 2017, p. 10), "a state that flouts the law and scoffs at the constitutional state" (Derrida, 2005, p. xiii), where many of these children are unaware of their parents' whereabouts due to unimaginable circumstances. Their presence in this strange place elicits a variety of reactions from the media and gains "space in the public gaze" (Lopeandia, 2021, p. 203): some are concerned about the possible causes of the unexpected influx of these unauthorised children; others lament the harsh conditions and systematic torture they must have endured at the border; still others encourage white Americans to protest against them (Luiselli, 2017, p. 14). Thus, the text leads us to call on the riveting book of Michelle Alexander's, entitled The New Jim Crow, where the writer represents how the brutality of slavery kept going through African-Americans' frequent incarceration in jails through the symbolic use of the Jim Crow image.

In this era of "postnationalism" (Sarmela, 2016, p. 1671), the United States "as a militaristic power with no respect for lives outside the First World" (Butler, 2004, p. 17) has remained "the most roguish of rogue states" because it makes "use of a concept like 'rogue state,' with the language, rhetoric, juridical discourse, and strategico-military consequences we all know" (Derrida, 2005, p. 96). Noam Chomsky (2000) shows that "the Inter-American Juridical Committee, which 
ruled unanimously that they violate international law, as did the Inter-American Commission on Human Rights" (p. 2). Like Luiselli, we do not know what these children might have felt, how they might have reacted, had they lived longer and fallen upon the thrones of life away from the metropolitan space of the United States. The writer gives an interesting analysis of America's infatuation with immigrant children, despite their unwelcome disposition, racism, and governmental hatred in their mere existence. In the end, she (2017) emphasises the hope that they might be able to repair for the sake of a better life in the form of the Teenage Immigrant Integration Association (TIIA), delivering moving speeches as part of frequent protests on Hofstra University's campus under the slogan "Refugees Welcome Here" (p. 102). Though "the refugee question has emerged as a major problem" (Agamben, 2021, p. 65) in the US, the ending of the

text advocates, to some extent, a kind of postnational cosmopolitanism through which "one should always view the good of humanity as a whole as one's goal" (Nussbaum, 2013, p. 473).

\section{References}

Agamben, Giorgio. (1995). "We Refugees." Symposium: A Quarterly Journal in Modern Literatures, 49 (2), 114-19. <http://dx.doi.org/10.1080/00397709.1995.10733798>. Accessed on 6 Sep. 2021.

---. (1998). Homo Sacer: Sovereign Power and Bare Life (Daniel Heller-Roazen, Trans.). Stanford University Press.

---. (1999). The Witness. In Daniel Heller-Roazen (Trans.), Remnants of Auschwitz: The Witness and the Archive (pp. 15-40). Zone Books.

---. (2000). Beyond Human Rights. In Vincenzo Binetti and Cesare Casarino (Trans.), Means Without End: Notes on Politics (pp. 15-28). University of Minnesota Press.

---. (2003). The State of Exception as a Paradigm of Government. In Daniel Heller-Roazen (Trans.), State of Exception (pp. 1-31). Stanford University Press.

---. (2021). Polemos Epidemios. In Valeria Dani (Trans.), Where are We Now? The Epidemic as Politics (pp. 59-71). Eris.

Alam, Fakrul. (2020). The English Writings: An Overview. In Sukanta Chaudhuri (Ed.), The Cambridge to Rabindranath Tagore (pp. 158-86). Cambridge University Press.

Alexander, Michelle. (2010). The New Jim Crow: Mass Incarceration in the Age of Colorblindness. The New Press.

Anzaldua, Gloria. (1987). The Homeland, Aztlan. In Borderlands La Frontera: The New Mestiza (pp. 1-14). Aunt Lute Books.

Banerjee, Paula. (2010). Circles of Insecurity: The Border People. In Borders, Histories, and Existences: Gender and Beyond (pp. 87-136). Sage Publisher.

Basu, Anustup. (2020). Questions Concerning the Hindu Political. In Hindutva as Political Monotheism (pp. 11-27). Duke University Press.

Behdad, Ali. (2005). Introduction: Nation and Immigration. In A Forgetful Nation: On Immigration and Cultural Identity in the United States (pp. 1-22). Duke University Press.

Browning, Robert. (1864). Christmas-Eve. In Sordello, Strafford, Christmas-Eve, and Easter-day (pp. 32573). Welch, Bigelow, and Company. 
Butler, Judith, and Athena Athanasiou. (2013). The logic of dispossession and the matter of the human (after the critique of metaphysics of substance). In Dispossession: The Performative and the Political (pp. 10-37). Polity Press.

Butler, Judith. (1997). Introduction: On Linguistic Vulnerability. In Excitable Speech: A Politics of the Performative (pp. 1-42). Routledge.

---. (2004). Explanation and Exoneration or What We Can Hear. In Precarious Life: The Power of Mourning and Violence (pp. 1-18). Verso.

---. (2009). Introduction: Precarious Life, Grievable Life. In Frames of War: When Is Life Grievable? (pp. 132). Verso.

---. (2015). Forward. In Isabell Lorey, State of Insecurity: Government of the Precarious (Aileen Derieg. Trans., pp. vii-xi). Verso.

Castellanos, Rosario. (1988). Fiction: Under a Man's Hand. In Maureen Ahren (Ed.), A Rosario Castellanos Reader: An Anthology of Her Poetry, Short Fiction, Essays, and Drama (pp. 31-8). University of Texas Press.

Chanda, Debajoy. (2021). "In Search of Other Worlds: The Dalit in De Facto Stateless in Avinash Dolas's The Refugee." Refugee Watch: A South Asian Journal on Forced Migration, 57, 44-61.

Chomsky, Noam. (2000). Rogues' Gallery: Who Qualifies. In Rogue States: The Rule of Force in World Affairs (pp. 1-11). South End Press.

Derrida, Jacques. (2005). Rogues: Two Essays on Reason (Pascale-Anne Brault and Michael Naas. Trans.). Stanford University Press.

Donnan, Hastings, and Thomas M. Wilson. (1999). Body Politics. In Borders: Frontiers of Identity, Nation and State (pp. 129-50). Berg Publishers.

During, Simon. (2005). The Discipline. In Cultural Studies: A Critical Studies (pp. 3-48). Routledge.

Fleuriet, K. Jill and Mari Castellano. (2020). "Media, Place-making and Concept-Metaphors: The US-Mexico Border during the Rise of Donald Trump." Media, Culture, and Society, 1-18. <https://doi.org/10.1177/0163443719890539>. Accessed on 27 Mar. 2021.

Folena, Lucia. (1989). Figures of violence: Philologists, witches, and Stalinistas. In Nancy Armstrong and Leonard Tennenhouse (Eds.), The Violence of Representation: Literature and the history of violence (pp. 219-38). Routledge.

Franco, Jean. (2002). Liberated Territories. In The Decline and Fall of the Lettered City: Latin America in the Cold War (pp. 86-120). Harvard University Press.

---. (2013). Introduction. In Cruel Modernity (pp. 1-22). Duke University Press.

Garcia Marquez, Gabriel. (2007). One Hundred Years of Solitude (Gregory Rabasa, Trans.). Penguin India. (Original work published in 1967).

Garrett, Terence M. (2020). "COVID-19, Wall Building, and the Effects on Migration Protection Protocols by the Trump Administration: The Spectacle of the Worsening Human Rights Disaster on the MexicoU.S. Border." Administer Theory and Praxis, 42 (2), 1-9.

Heyman, Josiah, Jeremy Slack, and Emily Guerra. (2018). "Bordering a 'crisis': Central American Asylum Seekers and the Reproduction of Dominant Border Enforcement Practices." Journal of the Southwest, 60(4), 754-84. <https://doi.org/10.1353/jsw.2018.0015>. Accessed on 9 Jan. 2021. 
Hinojosa-Ojeda, Raul and Edward Telles. (2021). Introduction. In Raul Hinojosa-Ojeda and Edward Telles (Eds.), The Trump Paradox. Migration, Trade, and Racial Politics (pp. 1-12). University of California Press.

Klingner, Donald. (2018). "Trump against the World: His Policies toward Mexico, and the Resistance from Inside and Outside the United States." Public Property, 20(1), 1-8. <http://doi.org/10.1080/10999922.2017.1368621>. Accessed on 23 Apr. 2021.

Leal, Luis. (1989). Juan Rulfo. In Carlos A. Sole (Ed.), Latin American Writer (pp. 1215-27). Charles Scribner's Sons.

Lopeandia, Nancy Nicholls. (2021). Pinochet's dictatorship and reflections on trauma in Chile: how much have we learned in terms of human rights? In Navras J. Aafreedi and Priya Singh (Eds.), Conceptualizing Mass Violence: Representations, Recollections, and Reinterpretations (pp. 197210). Routledge.

Luiselli, Valeria. (2017). Tell Me How It Ends. Coffee House Press.

Marti, Jose. (1963). Nuestra America. Editorial Nacional de Cuba.

Mukherjee, Sougata. (1998). Writing out of Solitude: "The Monstrous Reality" of Mexico. In Kavita Panjabi (Ed.), Nostalgia for the Future in Latin American (pp. 135-41). Jadavpur University Press.

Mukherjee, Indrani. (2011). The Transnational and Transgender in Latin American Texts Today. In Abin Chakraborty and Sayan Aich Bhowmick (Eds.), Uneven Terrains: Critical Perspectives in Postcolonialism (pp. 380-94). Booklore Publishers.

Nedoh, Bostjan. (2017). "Mass Migrations as a Messianic Event? Rereading Agamben's State of Exception in Light of the Refugee Crisis in Europe." Law, Culture and the Humanities, 1-18.

<https://doi.org/10.1177/1743872117703717>. Accessed on 18 Aug. 2021.

Nussbaum, Martha. (2013). "Climate Change: Why Theories of Justice Matter." Chicago Journal of International Law, 13, 469-85.

Owens, Patricia. (2009). "Reclaiming 'Bare Life'?: Against Agamben on Refugees." International Relations, $23(4), 567-82$.

Philips, James. (2014). "Agamben's limbos: Robert Walser and the refugee." Textual Practice, 28 (2), 289-303.

Rudrappa, Sharmila. (2008). Braceros and Techno-Braceros: Guest Workers in the United States, and the Commodification of Low-Wage and High-Wage Labour. In Susan Koshy and R. Radhakrishnan (Eds.), Transnational South Asians: The Making of a Neo-Diaspora (pp. 291-324). Oxford University Press.

Sarmela, Matti. (2016). Postnationalism. In John Stone (Ed.), The Wiley Blackwell Encyclopedia of Race, Ethnicity, and Nationalism (pp. 1671-81). Wiley.

Tuastad, Dag. (2016). "'State of exception' or 'state in exile'? The fallacy of appropriating Agamben on Palestinian refugee camps." Third World Quarterly, 38(9), 1-12.

Yates, Frances A. (1984). The Three Latin Sources for the Classical Art of Memory. In The Art of Memory (pp. 1-26). Ark Edition. 
11 Who Remembers those "Undocumented Minors"? Locating the Genealogy of the Oppressed in Valeria Luiselli's Tell Me How It Ends

Indrajit Mukherjee (M.A., Gold Medalist) is currently teaching as an Assistant Professor, Department of English, Nistarini College and pursuing his doctoral research at the Department of English Vidyasagar University. He has presented papers in AU, BU, BHU, IACLALS, IIT Madras, IIT Patna, and JU. He has many scholarly articles to his credit and is interested in Avant-Garde Theatre, Film Studies, Postcolonial Literature, and Romantic Studies. His latest publication is "We Are All Cyborgs Now': Disrupting Gender Identity through the Cyborg in Marge Piercy's He, She and It" (New Castle: Cambridge Scholars Publishing, 2021). 